HENRIKAS SIVILEVIČIUS, Ph.D. ${ }^{1}$

(Corresponding author)

E-mail: henrikas.sivilevicius@vgtu.It

LIJANA MASKELIŪNAITÉ, Ph.D. ${ }^{1}$

E-mail: lijana.maskeliunaite@vgtu.It

${ }^{1}$ Vilnius Gediminas Technical University

Faculty of Transportation Engineering

Department of Mobile Machinery and Railway Transport

Plytines str. 27, LT-10105, Vilnius, Lithuania
Transport Technology

Preliminary Communication

Submitted: 17 Jan. 2017

Accepted: 11 Oct. 2017

\title{
MULTIPLE CRITERIA EVALUATION AND THE INVERSE HIERARCHY MODEL FOR JUSTIFYING THE CHOICE OF RAIL TRANSPORT MODE
}

\begin{abstract}
The choice of a particular mode of transport as an alternative to another one is subjective and usually based on an individual passenger's approach to the evaluation of advantages and disadvantages of some particular means of transport. The paper presents the methods of analysing the reasons for passengers' choice of travelling by train as an alternative to using air transport and the results obtained in the research. The 16 criteria (sub-criteria), describing the advantages of travelling by rail over air travel, are defined. The data of the survey questionnaire filled by 52 passengers of the Vilnius-Moscow train and the ranks assigned by them to the considered criteria are described. The average ranks of all 16 criteria and their normalized subjective weights are calculated by using a new method of average rank transformation into weight (ARTIW). The average ranks assigned by the passengers of the train to sub-criteria and the calculated global weights show what criteria are most important. Using the inverse hierarchy model based on the sub-criteria weights, the most and the least important groups of criteria are determined. The institutions and companies engaged in passenger transportation by rail, which give priority to improving the services described by the most important criteria, can make this mode of transport more attractive to people.
\end{abstract}

\section{KEY WORDS}

rail transport; passenger transportation; evaluation criteria; inverse hierarchy; rank correlation; criteria weights; MCDM; ARTIW method;

\section{INTRODUCTION}

Customer perception of the quality of service provided by the operator and the level of satisfaction are one of the key parameters to monitor performance. Kesten and Öğüt [1] present a practical approach for monitoring public transportation system performance by focusing on the passengers' evaluations.
Mobility is vital for the internal market and for the quality of life of citizens as they enjoy their freedom to travel. The area where bottlenecks are still most evident is the internal market for rail services, which must be completed as a priority in order to achieve a single European railway area [2].

The systems of land transport (such as road and railway transport systems) are competing with air transport in the field of passenger transportation. Passengers usually choose a mode of transport that better satisfies their needs and conforms to their habits and notions about the trip quality. The choice of an alternative mode of transport is determined by the subjective weights of its evaluation criteria, which can be obtained by using Multiple Criteria Decision Making (MCDM) methods.

In Europe, travel by rail is popular because rail transport has some advantages over other modes of transport. Trips by train allow people to see the areas which cannot be reached by plane. Though more people apply to cheap flight agencies now, trips by train still remain one of the most suitable ways of seeing Europe. Trains can reach the most remote districts, and people can see constantly changing views through the train windows. They can freely use their mobile phones and the internet, arrive in the town centre and avoid traffic jams, as well as checking in for the flight and waiting for getting their luggage. Moreover, when travelling by train, one should not worry about the weather, as it happens when one chooses a trip by air transport. Travelling by train allows passengers to choose various types of tickets, including not only the tickets for a particular route, but those for several trips in a particular country, region and even in most parts of Europe.

Rail transport is still popular in the world, with Switzerland being a country where this mode of transport is most highly developed. Every day, 1.2 million of passengers use rail transport in this country. According to the data provided by UIC for 2014, every Swiss citizen 
made 59 trips by train in that period of time on the average. In this respect, "Swiss Railway" left behind such countries as Luxemburg (40 trips), as well as Denmark and Austria (29 trips each). In the middle of the list of the countries arranged by UIC in the priority order according to the trips by train made by their residents per year, are Spain, Sweden and Norway (from 3 to 12 trips by train). In the world, only Japanese make more trips by train than Swiss residents. Thus, in 2014, every Japanese resident made 72 trips by train on the average. Residents of Estonia, Lithuania and Romania are the least frequent users of rail transport in Europe. On the average, a Lithuanian resident travels by rail two times a year and covers a distance of 122 kilometres.

The aim of the trip can be chosen not only according to one's liking, but also depending on the mode of transport, e.g. travelling by bus, train or plane. The study of the mortality risks performed by the order of the Alliance for Natural Health (ANH) has shown that a person is at higher risk in their house than when travelling by train. A chance for a passenger travelling by rail transport to be killed in an accident is one to a million. The supporters of the informal "Slow Travel" movement emphasize that following its main principle we can help reduce the pollution of the environment. Therefore, the question is how to travel slowly. A possible answer is to choose travelling by train rather than by air transport. However, any mode of transport has its advantages and disadvantages.

Now, railways and railway vehicles are being improved all over the world. The level of passenger servicing is also being raised, and travel safety is being increased. This allows rail transport to successfully compete with other means of transport.

\section{LITERATURE REVIEW}

Lai et al. [3] developed an optimization framework with an alternative evaluator and an investment selector to determine an optimal investment plan with a specific allocation for cost, system reliability, and service reliability. The empirical case studies indicated that this optimization process can efficiently and successfully evaluate all of the possible alternatives and determine an optimal set of investments according to the design service reliability or life-cycle cost. This tool can help railway agencies and companies to maximize their return on investment and provide a reliable service to passengers.

The compatibility of the passenger flow variation values with the respective variations of the Russian Federation population has been analysed. The population dynamics and the dynamics of passenger departures in individual federal districts have been discussed [4]. The investigation has demonstrated that, in the present context, there is no universal trend linking the variations of population and passenger flow indices. One must admit that the number of inhabitants does not influence the passenger flow. Regression analyses have been performed to study the relationship between rail transit network parameters (e.g. length of line, age of the system, network topology) and city parameters (e.g. population, city area, population density) [5]. Transit ridership patterns in Europe, Asia and North America have also been investigated.

The effective work and popularity of ticket distribution channels of the companies providing passenger transportation services determine the competitiveness and commercial success of these companies [6]. The results yielded by the conducted comparative analyses of the average prices of the tickets realized via various distribution channels have shown the channels preferred by people with higher incomes.

A number of studies have been made to find the ways of improving the technical parameters of railways and rail vehicles, on which passenger travelling comfort and safety depend. It has been found that a weak railway subgrade may cause instability of the railway track system [7]. The problem of modelling railway track substructure has also been considered [8, 9]. Krakovskiy et al. [10] and Xu et al. [11] described the evaluation of the technical condition of the rails, while Povilaitienè et al. [12] described the possibility of decreasing rail wearing on the railway curve. Prestressed concrete sleepers present the most common type of the sleepers used on the railway. They serve as rail supports and absorb loads induced by trains. Sleepers are important for providing durability and safety of the railway and are subjected to various loads and the aggressive environment during their service [13].

Railway track irregularities are key factors affecting the safety of trains and the comfort of passengers [14]. The quality of the track geometry is highly dependent on ballast and substructure conditions. Currently, railways frequently use ballasted track, incurring high annual expenses for ballast maintenance and renewal. Track geometry maintenance (tamping) is used to compact ballast and correct track geometry faults, including incorrect alignment (lateral deviation) and incorrect longitudinal level (vertical deviation) [15]. Average annual maintenance and renewal (M\&R) expenditures per $1 \mathrm{~km}$ of tracks of advanced railway networks revolve around 50,000 euro nowadays [16].

The analysis of the factors leading to instability and derailment of railway cars has been made to ensure traffic safety $[17,18]$. It is well-known that the movement of trains at very high speeds (higher than 300 $\mathrm{km} / \mathrm{h}$ ) leads to high vibration on the railway track and its environment. The dynamic numerical model has been developed to solve the problem and tested in the real experimental measurement conditions [19]. 
Rusanov [20] formulated the problem of passive type safety protection of a passenger train colliding with an obstacle. Besides, he presented a procedure of preliminary parameter assessment of energy absorption devices mounted on the passenger train with the aim of reducing the damage to the health and the threat to the life of passengers in the train colliding with an obstacle.

In the revaluation of transit systems, cost estimating has always been a major consideration. In recent years, transit agencies in the United States have been building light rail transit (LRT) or bus rapid transit (BRT) systems to provide effective and reliable high-speed transit service. An integrated cost estimating model has been developed to provide a comprehensive cost estimating procedure for LRT and BRT systems aimed to improve the selection process to account for network effects in railway asset management [21]. This model has been implemented in real situations, with real networks and actual data for the transition probabilities and costs [22]. In the study of [23], a method for analysing the potential cost components of intermodal networks used in their design has been presented. This analysis could be useful both for airlines and rail companies in a qualitative analysis of their potential for intermodality.

The effects of rail transit on residential property values have been studied in [24]. The railway blocking problem (RBP) is one of the most important railway operation problems. Its solution is important for freight railway companies. The solution of the blocking problem considerably reduces the operational cost of railways and saves time in freight transportation. The proposed solution method has been applied to develop a blocking plan in Iran Railways and described in [25].

Li et al. [26] developed a model of the train route. This model considers speed limitation of rail vehicles and time of travel. Földes and Csiszár [27] offered a method of route planning evaluation. In Russia, railway workers are encouraged to use innovations designed to increase the efficiency and quality of the companies' management system [28]. Liao et al. [29] analysed the problems of providing services to passengers at Shanghai stations and the criteria used in evaluating their quality (for example, the influence of the station type, passenger gender, and passenger experience). Liao and Liu [30] investigated passenger behaviour in non-payment areas of rail transit stations using the cellular automata (CA) model. The queue selection model considers the dynamic distance between a current passenger and the dynamic end of a queue. This distance can be converted into the total travel time based on the average travel and service time. In 2012, the Massachusetts Bay Transportation Authority (MBTA) activated new real-time information signage across its heavy rail system. These signs displayed the estimated arrival of the next two trains in each direction [31]. One of the most important quality indicators of public transportation is punctuality. Deviations from the schedule decrease the level of service quality [32].

In passenger transportation, rail transport competes with some other modes of transport. In the present context, JSC Federal Passenger Company (JSC FPC), the acknowledged market leader in the segment of long-distance passenger transportation, experiences pressure from its traditional competitors providing bus and air services [33]. Therefore, searching for and introducing technological innovations which contribute to higher quality and attractiveness of railway services is of critical importance for retaining the positions of railway transport on the passenger transportation market.

Ballard and Osario [34] provided new public health data about the U.S. civil air shows. Risk factors for fatalities in civil show crashes have been analysed by using the regression methods. The civil air show crash rate was 31 crashes per 1,000 civil air events. Fatalities were associated with four major risk factors: fire, pilot error, aerobatic flight, and off-airport location.

The problems associated with passenger transportation by various modes are solved by using Multiple Criteria Decision Making (MCDM) methods. Madanu et al. [35] developed a multiple criteria and multimethod approach for evaluating the suitability of the alternative right-of-way (ROW) corridors to accommodate high-speed intercity passenger rail (HSIPR) operations. The paper has presented an integrated evaluation model that uses the methods based on fuzzy analytic hierarchy process (AHP) and fuzzy technique for order preference by similarity to ideal solution (TOPSIS) to address some of the issues. In their paper, Vitič-Četkovič and Bauk [36] positioned the passenger sea ports in the context of cruise tourism on the basis of e-services they offer. The e-services of eleven passenger ports have been categorized and quantitatively evaluated by binary and ranking approaches. The appropriate weight coefficients obtained by ranking (Saaty or AHP method) have been used in the process of the considered port final positioning on the cruise tourism e-market. The impact of the interaction of the transport system elements on traffic accident rate has been determined by the AHP method that allowed the authors [37] to calculate the weights of nine combinations of various types of interaction between the elements based on expert estimates.

The MCDM methods developed and used for modelling and evaluating the quality of passenger transportation by rail transport [38, 39] allowed the authors to obtain the estimates of the weights of the criteria describing this complicated process, which were assigned by passengers, as well as by serving and administration staff of the train. To increase the quality of railway trips, the interested parties, groups of people 
mentioned above, should coordinate their actions, cooperate with each other in solving the problems and exchange relevant information. Therefore, the increasing quality of passenger transportation is a complicated issue, requiring good professional skills based on knowledge, practical experience, high intellect and new ideas of all the people involved in this process [40]. Increasing the quality of services and other issues described by the criteria, it is possible to increase the competitiveness of rail transport on the market.

The present study aims to define a set of criteria showing rail transport advantages over air transport and to determine their average ranks, global and overall weights and consistency of the respondents' (passengers') estimates.

\section{AVERAGE CONSISTENCY LEVEL OF THE RESPONDENTS' ESTIMATES}

The weights of the evaluation criteria largely determine the evaluation result. In practice, subjective weights assigned by experts or respondents to the considered criteria are commonly used. The subjective weights present the judgements of highly qualified experts having long-term practical experience and theoretical knowledge in the considered field [41]. Passengers themselves make decisions about the mode of transport they choose for travel and, therefore, in a certain sense they are the experts. However, according to their competence, they should rather be considered the respondents answering the questionnaire questions.

The average estimate obtained in expert evaluation is assumed to be a solution to the problem (the evaluation result), if the judgements of all the experts are consistent (in agreement). When the solution is made based on the average estimate of the experts or respondents, the level of the consistency of their estimates should be determined. It is calculated by using the concordance coefficient $\mathrm{W}$, which can be used only if the ranks of the estimates assigned by the respondents or experts are given. If these estimates are expressed in other units (e.g. in points), they should be ranked.

The consistency of the estimates provided by a particular expert is determined by using the Analytic Hierarchy Process (AHP) suggested by Saaty [42, 43, 44]. To determine the consistency of the estimates provided by a group of experts, the method of ranks' correlation $[45,46]$ is used.

The concordance coefficient [45] is based on the sum of the ranks assigned by $n$ experts to each $j$-th criterion $R_{j}(j=1,2, \ldots m)$ :

$R_{j}=\sum_{i=1}^{n} R_{i j}$
More exactly, it is based on sum $S$ of the squared deviations $R_{j}$ (the variance analogue) from the mean rank $\bar{R}$ :

$S=\sum_{j=1}^{m}\left(R_{j}-\bar{R}\right)^{2}$

The average criterion rank $\bar{R}$ is obtained by dividing the sum of ranks, assigned to the criterion by the experts (respondents), by the number of the criteria, $m$ :

$\bar{R}=\frac{\sum_{j=1}^{m} R_{j}}{m}=\frac{\sum_{j=1}^{m} \sum_{i=1}^{n} R_{i j}}{m}=\frac{n(m+1)}{2}$

where $R_{i j}$ is the rank assigned by $i$-th respondent (expert) to $j$-th criterion; $n$ is the number of respondents (experts) $(i=1,2, \ldots, n) ; m$ is the number of the criteria $(j=1,2, \ldots, m)$.

If $S$ is a real square value calculated by Equation 2, the concordance coefficient $W$ is described (in the absence of the tied ranks) in terms of the relationship between the obtained $S$ value and the largest $S_{\max }$ [46]:

$W=\frac{12 S}{n^{2} m\left(m^{2}-1\right)}=\frac{12 S}{n^{2}\left(m^{3}-m\right)}$

When the estimates of the respondents or experts are in agreement, the value of the concordance coefficient $W$ is about one, but if these estimates differ to great extent, the value of $W$ is about zero.

The sum of the squared deviations of ranks $R_{i j}$ of each criterion from the mean rank can be calculated as follows:

$$
S=\sum_{j=1}^{m}\left[\sum_{i=1}^{n} R_{i j}-\frac{1}{2} n(m+1)\right]^{2}
$$

where $m$ is the number of criteria $(j=1,2, \ldots, m) ; n$ is the number of the respondents (experts) $(i=1,2, \ldots, n)$.

The value of the random number $S$ is calculated by adding together the squared values given to all the criteria, which are enclosed in square brackets (Equation 5).

The concordance coefficient can be used in practice if its limiting value, showing the condition when expert estimates may be considered consistent, is determined. Kendall [45] proved that when the number of the criteria is $m>7$ the confidence level of the coefficient $W$ could be determined using $\chi^{2}$ (Pearson's chi-squared test).

The random value

$\chi^{2}=W n(m-1)=\frac{12 S}{n m(m+1)}$

is distributed according to $\chi^{2}$, with the degree of freedom $v=m-1$. Based on the selected confidence level $\alpha$ (which is assumed to be 0.05 or 0.01 ), the critical value $\chi_{v, \alpha}^{2}$ is found from the table of $\chi^{2}$ distribution with the degree of freedom $n=m-1$. If the value of $\chi^{2}$ calculated by Equation 6 is larger than $\chi_{v, \alpha}^{2}$, it shows that the experts' (respondents') estimates are consistent. 
When the number of the compared criteria, $m$, ranges from 3 to $7, \chi^{2}$ distribution should be applied cautiously because the critical distribution value $\chi^{2} v$ could be larger than the calculated one (though the consistence of expert estimates would still be satisfactory). In this case, probability tables of the concordance coefficient or the tables of the critical values $S$ (with $3 \leq m \leq 7$ ) may be used [47].

The smallest value of the concordance coefficient $W_{\text {min }}$, allowing the researchers to assume that the judgements of $n$ experts about the quality of the investigated object described by $m$ criteria, with the specified confidence level $\alpha$ and the degree of freedom $v=m-1$, are consistent, can be calculated as follows:

$W_{\min }=\frac{\chi_{v, \alpha}^{2}}{n(m-1)}$

where $\chi_{v, \alpha}^{2}$ is the critical value, which is found in the table [48], assuming the degree of freedom $v=m-1$ and the confidence level $\alpha$.

When the quality of an object is assessed by the additive mathematical model used for calculating a complex qualitative criterion, which allows the quality of the investigated object to be described by a single value and compared with the quality of other similar objects, the normalized criterion weight coefficients $\omega_{j}$ should be used. The average criterion ranks $\bar{R}_{j}$ are not used because they do not show how much more important a particular criterion is with respect to another criterion.

The weights of the evaluation criteria of the research object (i.e. the criteria determining the choice of the trip by train rather than travel by plane) can be found by using a very popular but complex Analytic Hierarchy Process (AHP) approach offered by T. L. Saaty [42, 43, 44, 49]. Passengers are not highly qualified experts, and therefore, they can hardly fill in a pairwise comparison matrix appropriately, particularly, when the number of the evaluation criteria exceeds nine and reaches, for example, sixteen criteria.

The significances (weights) of the criteria describing the quality of an object are determined by experts, who normalize them (i.e. equate their sum to one) and use the method of average rank transformation into weight (ARTIW). This method was first presented in 2011 [50], but then it did not have the name ARTIW. The relative importance (weight) of any criterion is calculated by the equation:

$$
\omega_{j}=\frac{(m+1)-\bar{R}_{j}}{\sum_{j=1}^{m} \bar{R}_{j}}
$$

where $m$ is the number of criteria describing the quality (the essential features) of an object; $\bar{R}_{j}$ is the average rank of $j$-th criterion calculated by Equation 9 as follows:

$\bar{R}_{j}=\frac{\sum_{i=1}^{n} R_{i j}}{n}=\frac{R_{j}}{n}$ where $n$ is the number of experts or residents taking part in the evaluation.

The objective weights of the considered criteria and sub-criteria can be determined by using the entropy [51, 52] and new IDOCRIW [46] methods. The latter approach combines the entropy and the criterion impact loss (CILOS) methods.

\section{HIERARCHY MODEL, STRUCTURE OF THE QUESTIONNAIRE AND THE RESPONDENTS}

When passengers can travel from one town to another by various means of transport, they usually choose a mode of transport that seems to be more suitable and comfortable to them. The criteria determining the choice of a particular mode of transport can be identified when a set of the evaluation criteria is defined and a certain number of passengers are surveyed. The passengers, who chose a particular mode of transport (e.g. rail transport) as an alternative to another mode of transport, assign the ranks to the considered criteria. All the criteria describing the selected mode of transport have some advantages over the criteria describing the alternative mode of transport or are similar to them.

In a three-level hierarchy model, which is used in multiple criteria decision-making, the goal of the study is given first, then the criteria are presented and, finally, sub-criteria are provided [35, 53, 54, 55, 56, 57]. In this work, the inverse (not classical) hierarchy model (Figure 1) was used for determining the ranks of the criteria and their weights. Level 1 of the model presents the goal, Level 2 - factors and sub-criteria, and Level 3 provides a group of factors and criteria. First, the average ranks and global weights of particular sub-criteria were calculated without breaking them down into groups. Then, they were grouped into 3 groups, and the reduced weights of the criteria groups were calculated, taking into account the fact that each group had a different number of criteria.

The study was performed by surveying the passengers travelling from Vilnius (Lithuania) to Moscow (Russia) and back to Vilnius. There is good railway service between the capital of Lithuania, which is the EU member-state, and the capital of Russia. Therefore, the passengers have the opportunity to travel a distance of $944 \mathrm{~km}$ either by train or by plane.

A set of sub-criteria determining the choice of passengers to travel by train was defined when studying the reasons for their decision to use this mode of transport. The passengers who chose rail transport were asked to answer the question: Why am I riding in the train, but not in the plane? They were also asked to assign the ranks to the evaluation criteria, depending 


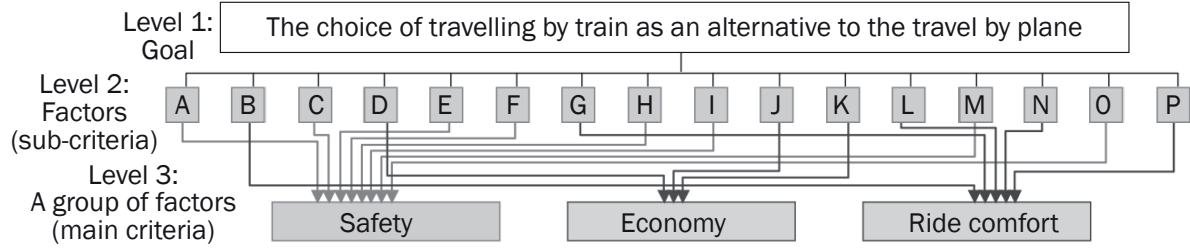

Figure 1 - The inverse hierarchy model of the factors (sub-criteria), determining the choice of passengers to travel by train rather than by plane

on their importance. The sub-criteria given below were included in the questionnaire provided to the passengers of the train (Figure 1):

A. In rail transport, the check-in does not take as long as in air transport;

B. The luggage can be taken by the passengers of the train exactly at the time of its arrival at the station (they need not wait for it long);

C. I prefer travelling by train because I am afraid of travelling by plane (because of air pockets, air toss, storms, etc.);

D. The difference in the time of travelling to a particular place by a fast train and by plane is not considerable;

E. Electronic devices of passengers need not be switched off in the train whereas this should be done in a plane (during take-off or landing);

F. A trip by train does not strongly depend on weather and cannot be delayed because of bad weather conditions;

G. Railway stations are close to the departure and arrival places of the train, while airports are far from the areas, where planes take off and land;

$H$. Safety belts should be fastened by the passengers of the plane when it is taking off or landing, while they are not used in the trains at all;

I. A danger of terrorists' attacks is greater in air transport than it is in rail transport;

J. An airplane emits more burnt gases into the air, polluting it more heavily than a rail vehicle, and consuming more fuel;

$\mathrm{K}$. A trip by train is cheaper than a trip by plane;

L. The occupancy of the space by passengers in the train is lower than that in the plane;

M. A person, buying a railway ticket or getting into the railway car, is not required to show a document

(e.g. a passport or an identification card), which is the case in air transport;

$\mathrm{N}$. The acceleration or deceleration of the train does not affect the passengers as strongly as does the plane's take-off or landing;

O. The luggage of all passengers in the train is not examined, and they can carry liquids;

P. The persons accompanying the passengers of the train can stay in the railway car until the train starts to depart.
A questionnaire was specially devised for a survey of passengers and the application of the method of ranks' correlation. This questionnaire was also translated into Russian. The anonymous survey of the passengers of the train Vilnius-Moscow-Vilnius was carried out in June 2015. The passengers had to fill in 52 questionnaires. In this survey, 24 Lithuanians, one Ukrainian, 26 Russians and one Lithuanian / Russian citizen took part. There were 24 women and 28 men among them. Most of the respondents had higher education (88.5\%) and were 46 years old on the average. This indicates that the majority of passengers were sufficiently qualified and able to make experience-based decisions (in selecting travel by train). The aims of their journey were associated with work (21 passengers), tourism (15 passengers), education (1 passenger), visiting relatives and friends (10 passengers) and medical treatment (5 passengers). The number of the respondents was 52 , which was more than 3 times the number of the considered sub-criteria (16). This means that the sufficient number of respondents took part in the survey $(n \geq m)$. A description of these 16 sub-criteria was provided in the questionnaires, where passengers assigned the ranks to each of them (the same ranks had not been found in the questionnaires).

\section{DETERMINING THE AVERAGE RANK, THE CONSISTENCY OF THE ESTIMATES OF RESPONDENTS AND THE WEIGHTS OF CRITERIA}

All sub-criteria (16) given in the questionnaire, which determined the choice of the passengers to travel by train rather than by plane, were divided into three groups according to their general goal (Figure 1). Eight sub-criteria (A, C, E, F, H, I, M, O) were included in the 'safety group', three sub-criteria $(D, J, K)$ made the 'economy group', and five sub-criteria (B, G, L, N, P) made the 'ride comfort group'.

The ranks of the importance (significance) of sub-criteria, determining the choice of travelling by train rather than by plane, which were assigned to them by the respondents, were used for calculating 


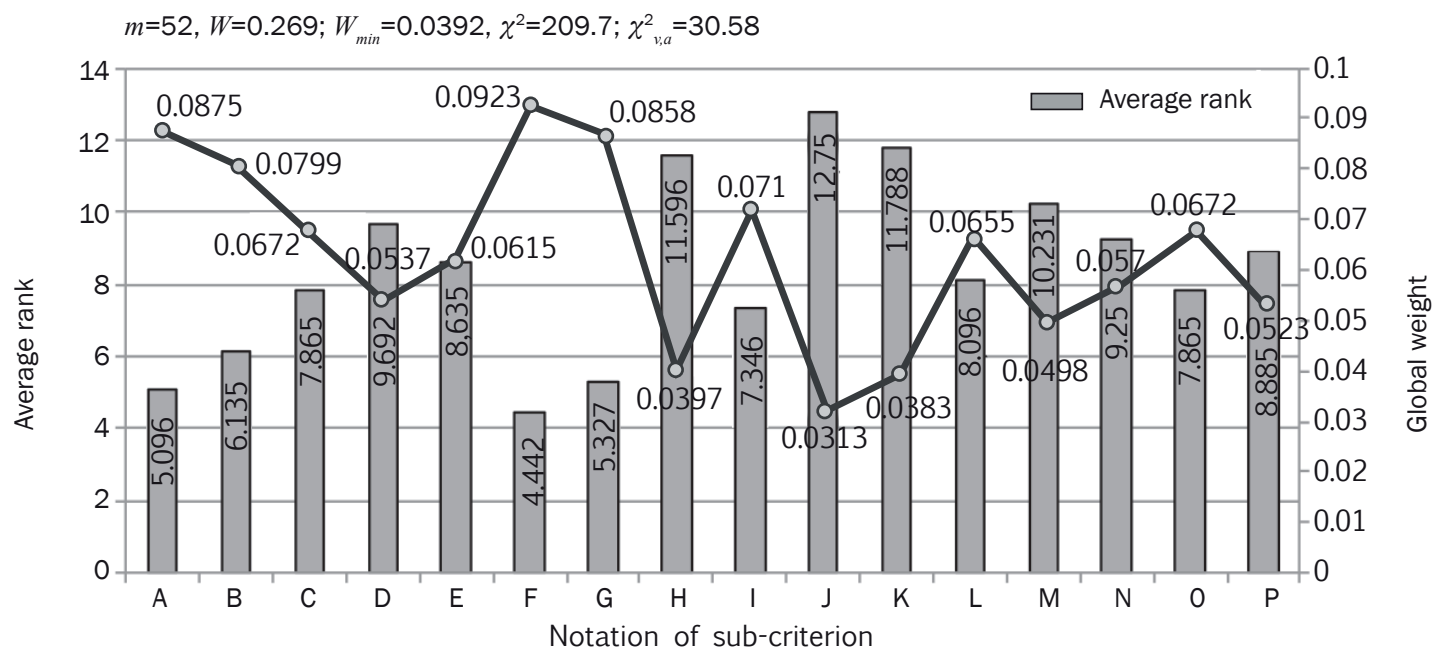

Figure 2 - The average ranks of sub-criteria $\bar{R}_{j}$ and their global weights $\omega_{j}$

the average ranks $\bar{R}_{j}$, the concordance coefficient $W$, Pearson's chi-squared test $\chi^{2}$ and the sub-criteria weights $\omega_{j}$.

The total sum of sub-criteria ranks was $\sum_{j=1}^{16} R_{j}=7,072$, while the sum of average ranks $\bar{R}_{j}$ of $j$ sub-criteria was $\sum_{j=1}^{16} \bar{R}_{j}=136.0$. The calculation of the average sub-criteria rank $\bar{R}=442$ which was per-

formed by using Equation 3, or some other mathematical operation, yielded $\bar{R}=7,072 / 16=442$ The sum of squared deviations $S=247,124$ (Equation 5). The concordance coefficient $W$, showing the consistence level of the estimates provided by a group of respondents (52 passengers of the train), which was calculated by Equation 4, was $W=0.269$.

Based on the data of the survey of passengers and using Equation 6, $\chi^{2}=209.7$ was obtained. The critical $\chi_{v, \alpha}^{2}$ value, taken from chi-squared test table, with the degree of freedom $v=16-1=15$ and the confidence level $\alpha=0.01$, was 30.5779. The empirical value $\chi^{2}=209.7$ was larger than the critical $\chi^{2}{ }_{v, \alpha}$; therefore, it could be concluded that the respondents' estimates were consistent.

The smallest value of the concordance coefficient $W_{\text {min }}$, with the confidence level $\alpha=0.01$ and the degree of freedom $v=m-1=16-1=15$, allowing us to assume that the respondents' estimates were consistent, was calculated by Equation 7. The smallest value of the concordance coefficient $W_{\text {min }}=0.0392$ was much smaller that the calculated concordance coefficient $W=0.269$.

A bar diagram of the calculated average ranks $\bar{R}_{j}$ of the sub-criteria determining the choice of travelling by train rather than by plane by the passengers is given in Figure 2.

By applying a new ARTIW method, the reasons for selecting a trip by train rather than a trip by plane by the passengers, which are described by sub-criteria and their weights $\omega_{j}$, were determined. The calculation data for sub-criteria from $A$ to $P$ are shown by a broken line in Figure 2. It was rather difficult to determine the weights $\omega_{j}$ of 16 sub-criteria by using the AHP approach because the optimal number of criteria (sub-criteria) for this method was seven plus or minus two [43, 49].

The calculated average ranks $\bar{R}_{j}$ (Figure 2 ) and global weights $\omega_{j}$ (Figure 3 ) of sub-criteria, determining the choice by the respondents of the trip by train rather than the travel by plane, show that sub-criteria F, A and $\mathrm{G}$ are much more important than sub-criteria J, K, $\mathrm{H}$. This implies that their priority order should be as follows: $\mathrm{F} \succ \mathrm{A} \succ \mathrm{G} \succ \mathrm{B} \succ \mathrm{I} \succ \mathrm{C} \succ \mathrm{O} \succ \mathrm{L} \succ \mathrm{E} \succ \mathrm{N} \succ \mathrm{D} \succ \mathrm{P} \succ \mathrm{M} \succ \mathrm{H} \succ \mathrm{K} \succ \mathrm{J}$.

Moreover, there should be the inverse straight-line relationship between the average ranks $\bar{R}_{j}$ and the global weights $\omega_{j}$ calculated by the ARTIW method. The determination coefficient of the regression equation of 16 sub-criteria, $R^{2}=1$, shows that this is a functional relationship $\omega_{j}=-0.0073 \bar{R}_{j}+0.125$ (Figure 3).

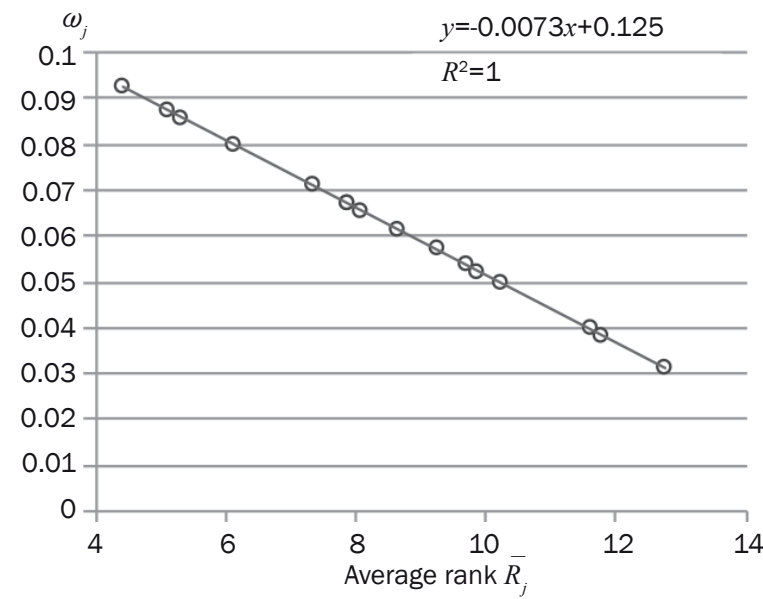

Figure 3 - The relationship between the weights $\omega_{j}$ and the average ranks $\bar{R}_{j}$ of sub-criteria 


\begin{tabular}{|c|c|c|c|c|c|c|c|c|c|c|c|c|c|c|c|c|c|}
\hline 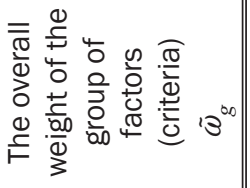 & \multicolumn{8}{|c|}{ 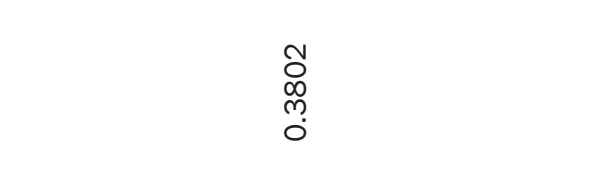 } & \multicolumn{3}{|c|}{$\begin{array}{l}\stackrel{m}{m} \\
\stackrel{N}{N} \\
0\end{array}$} & \multicolumn{5}{|c|}{$\begin{array}{l}10 \\
0 \\
0 \\
m \\
0 \\
0\end{array}$} & $\begin{array}{l}\text { ठ } \\
\text { ठ } \\
\text { - }\end{array}$ \\
\hline 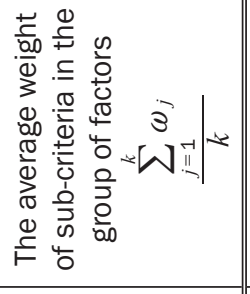 & \multicolumn{8}{|c|}{ 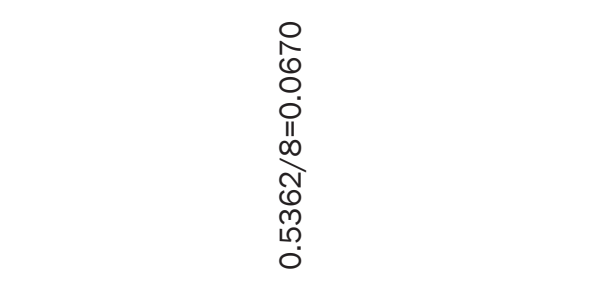 } & \multicolumn{3}{|c|}{ 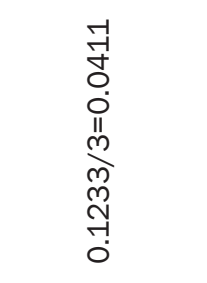 } & \multicolumn{5}{|c|}{$\begin{array}{l}\stackrel{1}{0} \\
0 \\
0 \\
0 \\
0 \\
\| 1 \\
0 \\
0 \\
0 \\
0 \\
\text { m. } \\
0\end{array}$} & 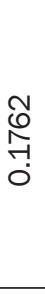 \\
\hline 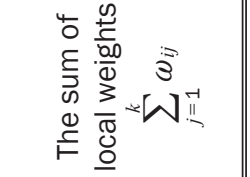 & \multicolumn{8}{|c|}{$\begin{array}{l}\text { ठ } \\
\stackrel{+}{+}\end{array}$} & \multicolumn{3}{|c|}{$\begin{array}{l}8 \\
8 \\
8 \\
\text { i }\end{array}$} & \multicolumn{5}{|c|}{$\begin{array}{l}8 \\
8 \\
8 \\
- \\
-\end{array}$} & $\begin{array}{l}8 \\
\delta \\
\dot{0} \\
\dot{m}\end{array}$ \\
\hline 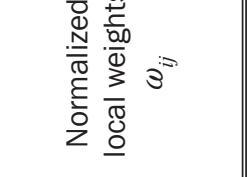 & $\begin{array}{l}\text { N్ } \\
0 \\
-1 \\
0\end{array}$ & $\begin{array}{l}\stackrel{M}{\stackrel{م}{n}} \\
\text { नै } \\
0\end{array}$ & $\begin{array}{l}\text { f } \\
\underset{7}{7} \\
\dot{0}\end{array}$ & $\underset{\stackrel{N}{N}}{\stackrel{-}{-1}}$ & $\begin{array}{l}\text { O⿱丶万仒 } \\
\text { 今. } \\
0\end{array}$ & 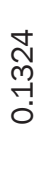 & $\begin{array}{l}\text { 尺े. } \\
\text { ̊े } \\
\text { ○. }\end{array}$ & 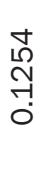 & $\begin{array}{l}\stackrel{\llcorner}{\stackrel{\rho}{\rho}} \\
\stackrel{\sim}{+} \\
\stackrel{0}{0}\end{array}$ & $\begin{array}{l}\text { लి } \\
\stackrel{N}{N} \\
\stackrel{0}{0}\end{array}$ & $\begin{array}{l}8 \\
\circ \\
\ddot{m} \\
0\end{array}$ & 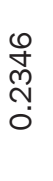 & 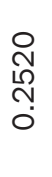 & 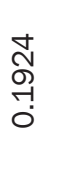 & $\begin{array}{l}\mathbb{t} \\
0 \\
\vdots \\
0 \\
0\end{array}$ & $\begin{array}{l}0 \\
\stackrel{N}{n} \\
\\
-1 \\
0\end{array}$ & $\begin{array}{l}\dot{8} \\
\dot{0} \\
\dot{m}\end{array}$ \\
\hline 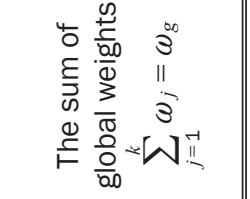 & \multicolumn{8}{|c|}{$\begin{array}{l}\text { N } \\
0 \\
\stackrel{0}{0} \\
0\end{array}$} & \multicolumn{3}{|c|}{ 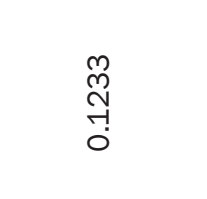 } & \multicolumn{5}{|c|}{$\begin{array}{l}\text { مी } \\
\text { ఫे } \\
\text { m. } \\
0\end{array}$} & $\begin{array}{l}8 \\
8 \\
\text { - } \\
\text { - }\end{array}$ \\
\hline 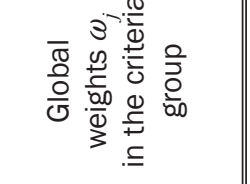 & $\begin{array}{l}10 \\
م \\
\infty \\
0 \\
0 \\
0\end{array}$ & 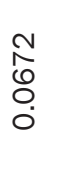 & $\begin{array}{l}\qquad 7 \\
\stackrel{1}{0} \\
0 \\
0\end{array}$ & $\begin{array}{l}\text { N. } \\
\text { هे } \\
\text { O. }\end{array}$ & $\begin{array}{l}\hat{\sigma} \\
\text { లె } \\
0 \\
0\end{array}$ & 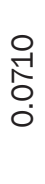 & $\begin{array}{l}\infty \\
\text { O } \\
\\
\\
\circ\end{array}$ & \begin{tabular}{l}
\multirow{N}{*}{} \\
0 \\
0 \\
0
\end{tabular} & $\begin{array}{l}\hat{N} \\
\stackrel{0}{0} \\
\stackrel{0}{0}\end{array}$ & $\begin{array}{l}\stackrel{m}{M} \\
\ddot{m} \\
\stackrel{0}{0}\end{array}$ & $\begin{array}{l}\infty \\
\infty \\
\infty \\
0 \\
0 \\
0\end{array}$ & \begin{tabular}{l} 
g \\
\multicolumn{1}{c}{} \\
0 \\
$\circ$ \\
0
\end{tabular} & $\begin{array}{l}\infty \\
1 \\
\infty \\
0 \\
0 \\
0\end{array}$ & $\begin{array}{l}\stackrel{1}{\Omega} \\
\stackrel{0}{0} \\
0 \\
\circ\end{array}$ & $\begin{array}{l}0 \\
\stackrel{0}{0} \\
0 \\
0 \\
0\end{array}$ & $\begin{array}{l}\text { N } \\
\text { Vె. } \\
0 \\
0 \\
0\end{array}$ & $\begin{array}{l}8 \\
8 \\
0 \\
- \\
-\end{array}$ \\
\hline 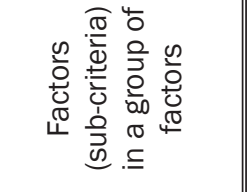 & $\ll$ & 0 & ш & \llcorner & $I$ & - & $\Sigma$ & 0 & ○ & $\neg$ & $x$ & 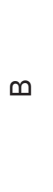 & 0 & \lrcorner & $z$ & a & ' \\
\hline 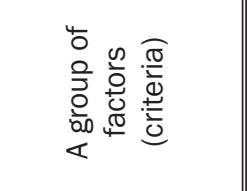 & \multicolumn{8}{|c|}{ 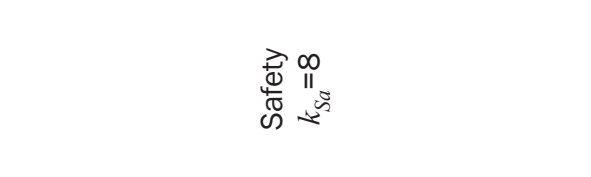 } & \multicolumn{3}{|c|}{ 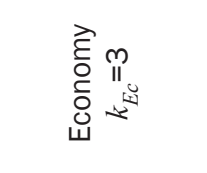 } & \multicolumn{5}{|c|}{ 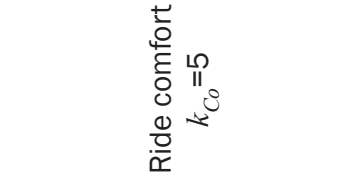 } & \\
\hline 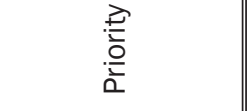 & $\sim$ & 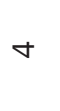 & 0 & $ન$ & $\sigma$ & 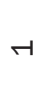 & $m$ & $\underset{\neg}{\sharp}$ & เ & $\stackrel{\varphi}{r}$ & $\stackrel{\text { Lி }}{\circ}$ & $\infty$ & $\stackrel{m}{\rightarrow}$ & 아 & $\wedge$ & ㄱ & ' \\
\hline 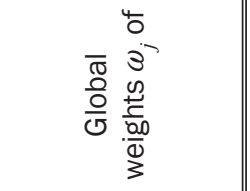 & $\begin{array}{l}\frac{1}{0} \\
\infty \\
0 \\
0 \\
0\end{array}$ & 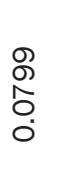 & $\begin{array}{l}\mathbb{N} \\
\hat{\theta} \\
0 \\
0\end{array}$ & $\begin{array}{l}\hat{m} \\
\stackrel{0}{0} \\
0 \\
0\end{array}$ & $\begin{array}{l}\stackrel{1}{7} \\
\stackrel{0}{0} \\
0 \\
0\end{array}$ & $\begin{array}{l}\text { W } \\
\text { Oे. } \\
\text { ○. }\end{array}$ & $\begin{array}{l}\infty \\
1 \\
\infty \\
0 \\
0 \\
0\end{array}$ & $\begin{array}{l}\text { के } \\
\text { Oे } \\
\text { ¿. }\end{array}$ & $\begin{array}{l}0 \\
\text { ㄱ. } \\
0 \\
0\end{array}$ & $\begin{array}{l}\stackrel{m}{M} \\
\ddot{m} \\
\stackrel{0}{0}\end{array}$ & $\begin{array}{l}m \\
\infty \\
\dddot{m} \\
0 \\
\dot{0}\end{array}$ & $\begin{array}{l}10 \\
10 \\
0 \\
0 \\
\circ \\
0\end{array}$ & $\begin{array}{l}\infty \\
o \\
\\
0 \\
0\end{array}$ & $\begin{array}{l}0 \\
10 \\
0 \\
0 \\
0\end{array}$ & 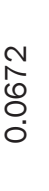 & \begin{tabular}{l} 
N \\
\multirow{2}{0}{} \\
0 \\
0
\end{tabular} & $\begin{array}{l}\text { ठ } \\
\text { ठ } \\
\text { - }\end{array}$ \\
\hline 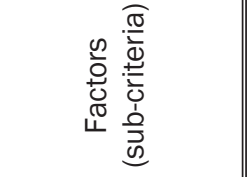 & $\ll$ & $\infty$ & 0 & 0 & ш & ᄂ & $\sigma$ & I & - & $\neg$ & $\underline{x}$ & \lrcorner & $\Sigma$ & $z$ & 0 & a & 嵒 \\
\hline
\end{tabular}




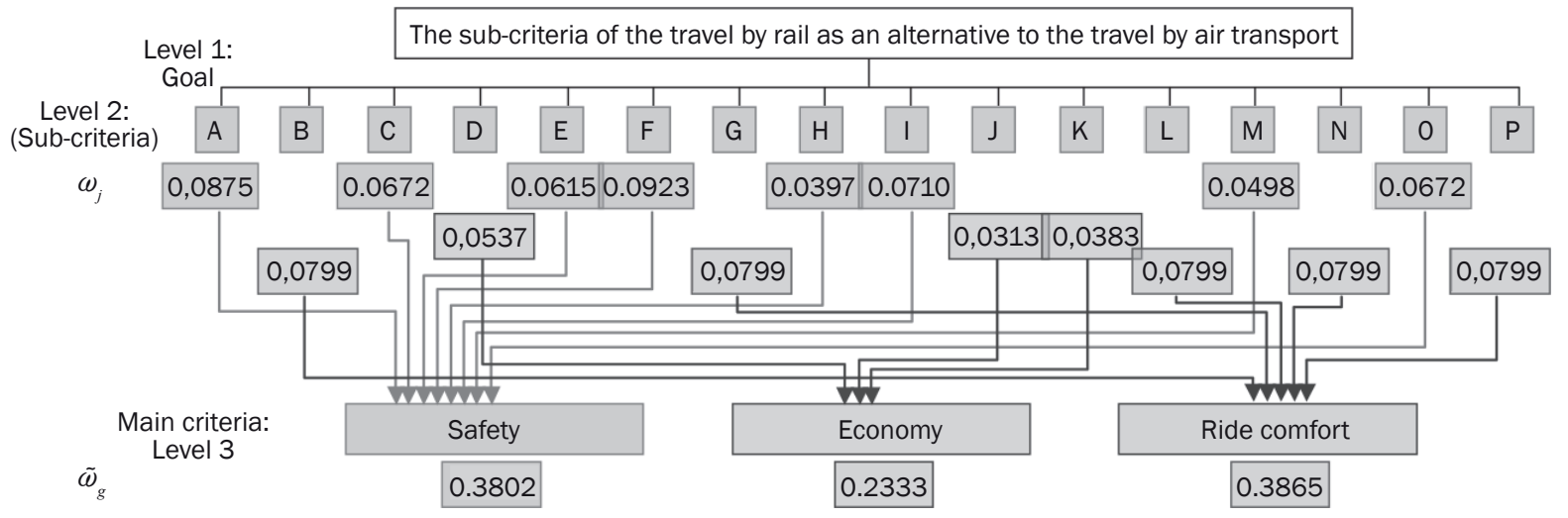

Figure 4 - The calculated subjective weights of sub-criteria and the criteria of various groups

The data obtained in the study show that the railway passengers' estimates of the importance of sub-criteria, determining their choice of this mode of transport (rather than air transport), are consistent (in agreement) and reflect their general opinion.

\section{CALCULATION OF THE OVERALL WEIGHTS OF THE MAIN CRITERIA}

Having calculated the global weights $\omega_{j}$ of all 16 sub-criteria and having divided these sub-criteria into three groups as shown in Figure 1, we could calculate the overall sub-criteria weights of the criteria groups $\tilde{\omega}_{g}$ (Table 1) by the equation:

$$
\widetilde{\omega}_{g}=\frac{\sum_{j=1}^{k} \omega_{j} / k}{\sum_{b=1}^{g} \sum_{j=1}^{k} \omega_{j} / k}
$$

where $\omega$ is the global weight of $j$-th sub-criterion; $k$ is the number of sub-criteria in the group $(j=1,2, \ldots, k) ; g$ is the number of criteria (sub-criteria groups) of the research object $(b=1,2, \ldots, g)$.

The weight $\tilde{\omega}_{S a}$ of eight sub-criteria, $\mathrm{A}+\mathrm{C}+\mathrm{E}+\mathrm{F}+\mathrm{H}+\mathrm{I}+\mathrm{M}+\mathrm{O}$, making the 'safety group', was calculated by Equation 10 as follows:

$$
\widetilde{\omega}_{S a}=\frac{0.5362: 8}{0.0670+0.0411+0.0681}=0.3802 \text {. }
$$

Weight $\tilde{\omega}_{E c}$ of three sub-criteria, $\mathrm{D}+\mathrm{J}+\mathrm{K}$, making the 'economy group', which was calculated in a similar way, was the smallest:

$$
\widetilde{\omega}_{E c}=\frac{0.1233: 3}{0.0670+0.0411+0.0681}=0.2333 \text {. }
$$

Weight $\tilde{\omega}_{C o}$ of five sub-criteria, $\mathrm{B}+\mathrm{G}+\mathrm{L}+\mathrm{N}+\mathrm{P}$, making the 'ride comfort group', which was calculated in the same way, was the largest:

$$
\widetilde{\omega}_{C o}=\frac{0.3405: 5}{0.0670+0.0411+0.0681}=0.386 \text {. }
$$

The obtained calculation results show that railway passengers have chosen a trip by train as an alternative to a trip by plane because of the comfort (about $39 \%$ ), safety (about 38\%) and economy (only about
$23 \%)$ of travelling by rail transport. The 'economy' group criterion (sub-criteria $\mathrm{D}, \mathrm{J}$ and $\mathrm{K}$ ) is of least importance to passengers who selected travel by train as an alternative to plane, since ticket price and reducing environmental pollution were not as relevant as comfort and safety determining factors: passengers who travelled by train were wealthy or travelled to professional traineeships.

The global weights $\omega_{j}$ of the sub-criteria used in the study and the overall weights of criteria divided into three groups $\tilde{\omega}_{g}$, which are given in Figure 4, allowed the authors to define the criteria, determining the choice of the trip by train rather than the travel by plane by the considered passengers. These data can help to determine the ways of increasing the quality of passenger transportation by rail so that this mode of land transport could effectively compete with air transport.

\section{CONCLUSIONS}

Passengers, having the possibility to travel from one place to another by various means of transport, choose a mode of transport which seems to be more suitable (or attractive) to them according to their personal experience and attitudes, largely depending on advertising. Usually, passengers make a choice of a particular mode of transport by considering the factors (evaluation criteria), whose significances (weights) are different from their point of view. The choice of the alternative mode of transport is determined by the significances of the main criteria describing it (i.e. the subjective weights). These weights can be obtained by using the expert method. The average estimate of the criteria ranks or weights assigned by a great number of passengers (respondents) can be used as a result, showing the public opinion in choosing a means of transport for a particular route.

In the present study, the reasons for choosing a trip by train rather than a trip by plane by passengers are described by sixteen sub-criteria. The importance 
of these sub-criteria for choosing a particular mode of transport was evaluated by 52 respondents (the passengers of the Vilnius-Moscow-Vilnius train) against the scale of sixteen ranks. The subjective global normalized weights of sub-criteria calculated by the novel ARTIW method allowed the authors to arrange them in the order of preference, showing the main reasons (expressed by sub-criteria), why passengers preferred the trip by train over the trip by plane. This choice was primarily determined by the independence of the trip by train from weather conditions (0.0923), a shorter boarding time $(0.0875)$ and the location of railway stations (which are nearer to passengers than airports) (0.0858). Less important sub-criteria included the arrival of the passengers' luggage together with them (0.0799), a higher threat of terrorism on the plane (0.0710), fear of people to travel by plane $(0.0672)$ and the absence of luggage examination on the train (0.0672). Other groups of less important sub-criteria included larger spaces on the train (0.0655), the requirement to passengers to switch off their electronic devices on the plane (0.0615), lower acceleration of the train (0.0570), a shorter trip by a fast train (0.0537) and the possibility of the people accompanying a passenger to stay in the train until it departs $(0.0523)$. The least important sub-criteria included the identity check of people buying tickets for a trip by plane and during boarding (0.0498), the requirement to passengers to fasten safety belts on the plane (0.0397), the availability of cheaper tickets for a trip by train in some periods of time (0.0393), as well as lower pollution of the environment and lower fuel consumption by rail vehicles (0.0313). The ratio of the largest values $(0.0923)$ to the smallest values $(0.0313)$ of the global weights of sub-criteria (2.95) shows that sub-criteria determining the choice of the mode of transport by passengers are of different importance.

The estimates of the criteria importance, provided by all 52 passengers taking part in the survey, are consistent because the calculated concordance coefficient is equal to 0.269 , and Pearson's chi-squared test value (209.7) is much higher than the critical value, which is equal to 30.57 , with the degree of freedom of 15 and the confidence level of 0.01 . The concordance coefficient value of 0.269 is about seven times as large as its smallest value (0.0392), allowing us to assume that the estimates of all respondents are consistent. A very high consistence level of the respondents' estimates (with the concordance coefficient about one) could hardly be expected because the experience, habits, wishes and possibilities of passengers were completely different.

Sixteen sub-criteria were divided into three groups based on using the inverse hierarchy model, and their normalized overall weights were calculated. The overall weight of eight sub-criteria making the 'safety' criterion was found to be equal to 0.3802 , while the overall weight of three sub-criteria forming the 'economy' criterion was 0.2333 , and the weight of five criteria making the 'ride comfort' criterion was equal to 0.3865 (the largest overall weight). These results indicate that on a personal level, a passenger perceives comfort and safety of travelling by train as more important than economic factors. Most often international train is selected by opulent people who are on profession-related business trip to another country. The overall weights of the criteria of any sub-criteria group were calculated using a new method, allowing for ignoring the influence of the number of sub-criteria in each group.

The decision makers of "Lietuvos geležinkeliai" company, engaged in passenger transportation by the considered international train, should primarily improve the services described by the criteria, most strongly influencing a decision of passengers to choose a trip by train rather than a trip by plane. A company providing passenger transportation by any particular means of transport can win the competition in this area only if the provided services are of the highest quality and satisfy the the ever-growing demands of passengers.

Prof. habil. dr. HENRIKAS SIVILEVIČIUS, C.Sc., Ph.D., Ing. ${ }^{1}$

E-mail: henrikas.sivilevicius@vgtu.It

Doc. dr. LIJANA MASKELIŪNAITÉ ${ }^{1}$

E-mail: lijana.maskeliunaite@vgtu.It

${ }^{1}$ Transporto inžinerijos fakultetas

Mobiliujų mašinų ir geležinkelių transporto katedra

Vilniaus Gedimino technikos universitetas

Plytinès g. 27, LT-10105, Vilnius, Lietuva

\section{DAUGIAKRITERINIO IVERTINIMO IR ATVIRKŠTINĖS HIERARCHIJOS MODELIS, PAGRINDŽIANTIS PASIRINKIMA KELIAUTI GELEŽINKELIU TRANSPORTU}

\section{SANTRAUKA}

Vienos transporto rūšies pasirinkimą kaip alternatyvą kitai transporto rūšiai dažniausiai nulemia keleivio asmeniškai palyginamu transporto rūšiu privalumai ir trūkumai. Darbe pateikiama keleiviu pasirinkimo kelionès traukiniu kaip alternatyvos oro transportui tyrimo metodika ir rezultatai. Sudaryta 16 veiksniu (subkriteriju), rodančiu geležinkeliu transporto privalumus oro transportui, anketa. Anketą užpildė 52 tarptautinio traukinio Vilnius-Maskva keleiviai, suteikdami subkriterijams rangus. Apskaičiuoti visu 16 veiksniu vidutiniai rangai ir normalizuotieji subjektyvūs svoriai taikant naują average rank transformation into weight (ARTIW) metodą. Keleiviu vertinimu vidutiniai rangai ir globalūs svoriai rodo, kurie veiksniai traukinio keleiviams yra svarbiausi ir kurie mažiau svarbūs. Taikant atvirkštinès hierarchijos modeli iš subkriteriju svoriu nustatyta, kad važiavimo komforto veiksniu grupé keleiviams yra svarbiausia, vidutinio svarbumo yra saugumo veiksniu grupe ir mažiausiai svarbi yra ekonominiu veiksniu grupé. Keleiviu vežimą geležinkeliais organizuojančios ir vykdančios institucijos, sutelkusios prioritetinius veiksmus svarbiausiems kriterijams gerinti, gali padidinti geležinkelių transporto patrauklumą. 


\section{RAKTINIAI ŽODŽIAI}

geležinkeliu transportas; keleiviu vežimas; vertinami kriterijai; atvirkštinè hierarchija; rangu koreliacija; kriteriju svoriai; MCDM; ARTIW metodas;

\section{REFERENCES}

[1] Kesten AS, Öğüt KS. A new passenger-oriented performance measurement framework for public rail transportation systems. Promet - Traffic \& Transportation. 2014;26(4): 299-311. Available from: http://dx.doi. org/10.7307/ptt.v26i4.1314

[2] European Commission. Directorate - General for Mobility and Transport. Roadmap to a Single European Transport Area-Towards a Competitive and Resource-Efficient Transport System. White Paper 2011, 2011.

[3] Lai Y-C (R), Lu C-T, Hsu Y-W. Optimal allocation of life-cycle cost, system reliability, and service reliability in passenger rail system design. Transportation Research Record. 2015;2475: 46-53. Available from: doi:10.3141/2475-06

[4] Surzhin KV, Muktepavel SV. Otsenka vliyaniya faktorov chislennosti naseleniya na ob'em passazhirskikh perevozok. Vestnik VNIIZhT. 2015;4: 59-64. Russian

[5] Saidi S, Wirasinghe SC, Kattan L. Rail transit. Exploration with emphasis on networks with ring lines. Transportation Research Record. 2014;2419: 23-32. Available from: doi:10.3141/2419-03

[6] Komisarov AV, Martynova EA, Sokolovsky AV, Samusev RV. Aktual'nye trendy v razvitii kanalov sbyta biletov na poezda dal'nego sledovaniya na primere biznes-napravleniya "Prodamsi" federal'noy passazhirskoy kompanii. Vestnik VNIIZhT. 2014;6: 13-20. Russian

[7] Byun Y-H, Kim J H, Lee J-S. Cone penetrometer with a helical-type outer screw rod for evaluation of the subgrade condition. Journal of Transportation Engineering. 2013;139(2): 115-122. Available from: doi:10.1061/(ASCE)TE.1943-5436.0000504

[8] Gallego I, Muñoz J, Sánchez-Cambronero S, Rivas A. Recommendations for numerical rail substructure modelling considering nonlinear elastic behaviour. Journal of Transportation Engineering. 2013;139(8): 848-858. Available from: http://dx.doi.org.10.1061/ (ASCE)TE.1943-5436.00005604

[9] Navikas D, Bulevičius M, Sivilevičius H. Determination and evaluation of railway aggregate sub-ballast gradation and other properties variation. Journal of Civil Engineering and Management. 2016;22(5): 699-710. Available from: doi:10.3846/13923730.2016.1177586

[10] Krakovskiy YM, Nachigin VA, Nachigin AV. Otsenka tekhnicheskogo sostoyanie rel'sov po dannym monitoringa puti. Vestnik VNIIZhT. 2012;5: 40-43. Russian

[11] Xu P, Sun Q, Liu R, Wang F. A short-range prediction model for track quality index. Proceedings of the Institution of Mechanical Engineers Part F: Journal of Rail and Rapid Transit. 2011;225(3): 277-285. Available from: doi:10.1177/2041301710392477

[12] Povilaitienè I, Kamaitis IZ, Podagèlis I. Influence of gauge width on rail side wear on track curves. Journal of Civil Engineering and Management. 2006;11(3): 255-260.

[13] Jokūbaitis A, Valivonis J, Marčiukaitis G. Analysis of strain state and cracking of concrete sleepers. Journal of Civil Engineering and Management. 2016;22(4):
564-572. Available from: doi:10.3846/13923730.20 16.1147494

[14] Bai L, Liu R, Sun Q, Wang F, Wang F. Classification-learning-based framework for predicting railway track irregularities. Proceedings of the Institution of Mechanical Engineers, Part F: Journal of Rail and Rapid Transit. 2016;230(2): 598-610. Available from: doi:10:1177/0954409714552818

[15] Arasteh Khouy I, Larsson-Kråik P-O, Nissen A, Kumar U. Cost-effective track geometry maintenance limits. Proceeding of the Institution of Mechanical Engineers, Part F: Journal of Rail and Rapid Transit. 2016;230(2): 611-622. Available from: doi:10.1177/0954409714542859

[16] Jovanovič S, Božovič D, Tomičič-Torlakovič M. Railway infrastructure condition-monitoring and analysis a basis for maintenance management. Građevinar. 2014;66(4): 347-358. Available from: doi:10.14256/ JCE959.2013

[17] Cheng Y-C, Hsu C-T. Hunting stability and derailment analysis of a car model of a railway vehicle system. Proceeding of the Institution of Mechanical Engineers, Part F: Journal of Rail and Rapid Transit. 2011;226: 187-202. Available from: doi:10.1177/0954409711407658

[18] Wu X, Chi, M, Gao H, Zhang D, Zeng J, Wu P, Zhu M. The study of post-derailment measures to limit the extent of a derailment. Proceedings of the Institution of Mechanical Engineers, Part F: Journal of Rail and Rapid Transit. 2016;230 (1): 64-76. Available from: doi:10.1177/0954409714526586

[19] Ferreira PA, López-Pita A. Numerical modeling of highspeed train/track system to assess track vibrations and settlement prediction. Journal of Transportation Engineering. 2013;139(3): 330-337. Available from: doi:10.1061/(ASCE)TE.1943-5436.0000482

[20] Rusanov OA. Ocenka parametrov ustrojstv pogloshchenija energiy avarijnovo stolknovenija passazhirskovo podvizhnovo sostava s prepiatstviem. Vestnik VNIIZhT. 2014;1: 8-18. Russian

[21] Hsu LR. Cost estimating model for mode choice between light rail and bus rapid transit systems. Journal of Transportation Engineering. 2013;139(1): 20-29. Available from: http://dx.doi.org.10.1061/(ASCE) TE.1943-5436.0000466

[22] Furuya A, Madanat S. Accounting for network effects in railway asset management. Journal of Transportation Engineering. 2013;139(1): 92-100. Available from: http:// dx.doi.org.10.1061/(ASCE)TE.1943-5436.0000477

[23] Allard RF, Vilaça e Maura FMM. Optimizing high-speed rail and air transport intermodal passenger network design. Transportation Research Record. 2014;2448: 11-20. Available from: doi:10.3141/2448-02

[24] Pan Q, Pan H, Zhang M, Zhong B. Effects of rail transit on residential property values. Transportation Research Record. 2014;2453: 118-127. Available from: http://dx.doi.org.10.3141/2453-15

[25] Yaghini M, Ahadi HR, Barati E, Saghian Z. Tabu search algorithm for the railroad blocking problem. Journal of Transportation Engineering. 2013;139(2): 216222. Available from: doi:10.1061/(ASCE)TE.19435436.0000447

[26] Li F, Gao Z, Li K, Wang DZW. Train routing model 
and algorithm combined with train scheduling. Journal of Transportation Engineering. 2013;139(1): 81-91. Available from: doi:10.1061/(ASCE)TE.19435436.0000461

[27] Földes D, Csiszár C. Route plan evaluation method for personalised passenger information service. Transport. 2015;30 (3): 273-285. Available from: http:// dx.doi.org.10.3846/16484142.2015.1086889

[28] Tolkachyova MM, Pisarevskiy GE, Martynova LA, Lomakina NM. Motyvacija rabotnikov OAO „RZhD“ k vnedreniju inovaciy $v$ korporativnoj sisteme upravlenija povysheniem effektivnosti i kachestva. Problemy i ikh reshenija. Vestnik VNIIZhT. 2014;2: 3-12. Russian

[29] Liao M, Liu G, Qiu TZ. Passenger traffic characteristics of service facilities in rail transit stations of Shanghai. Journal of Transportation Engineering. 2013;139(2): 223-229. Available from: doi:10.1061/(ASCE) TE.1943-5436.0000481

[30] Liao M, Liu G. Modelling passenger behaviour in non-payment areas at rail transit stations. Transportation Research Record. 2015;2534: 101-108. Available from: doi:10.3141/2534-13

[31] Chow W, Schachter-Block D, Hickey S. Impacts of real-time passenger information signs in rail stations at the Massachusetts bay transportation authority. Transportation Research Record. 2014;2419: 1-10. Available from: http://dx.doi.org.10.3141/2419-01

[32] Nagy E, Csiszár C. Analysis of delay causes in railway passenger transportation. Periodica Politechnica Transportation Engineering. 2015;43(2): 73-80. Available from: doi:10.3311/PPtr.7539

[33] Makarova EA, Sokolovsky AV. Metodika analyticheskih issledovanij dla opredelenija celesobraznosti vvoda v obraschenie passazhirskih poezdov s zhostkoj schemoj sostava. Vestnik VNIIZhT. 2014;4: 33-38. Russian

[34] Ballard S-B, Osario VB. U.S. Civil air show crashes, 1993 to 2013. Burden, fatal risk factors, and evaluation of a risk index for aviation crashes. Transportation Research Record. 2015;2471: 1-9. Available from: doi:10.3141/2471-01

[35] Madanu SK, Mattingly SP, Kam KA, Ardekani SA. Integrated fuzzy technique for order preference by similarity to ideal solution framework for evaluating high-speed passenger rail corridor alternatives. Transportation Research Record. 2015;2499: 1-19. Available from: doi:10.3141/2499-01

[36] Vitić-Ćetković A, Bauk S. E-services and positioning of passenger ports in the context of cruise tourism promotion. Promet - Traffic \& Transportation. 2014;26(1): 83-93. Available from: http://dx.doi.org/10.7307/ptt. v26i1.1282

[37] Podvezko V, Sivilevičius H. The use of AHP and rank correlation methods for determining the significance of the interaction between the elements of a transport system having a strong influence on traffic safety. Transport. 2013;28(4): 389-403. Available from: doi:1 $0.3846 / 16484142.2013 .866980$

[38] Sivilevičius H, Maskeliūnaitè L. The criteria for identifying the quality of passengers' transportation by railway and their ranking using AHP method. Transport. 2010;25(4): 368-381. Available from: doi: 10.3846/ transport.2010.46

[39] Maskeliūnaitè L, Sivilevičius H. The model for evaluating the criteria describing the quality of the trip by international train. Technological and Economic Development of Economy. 2014;20(3): 484-506. Available from: http://dx.doi.org.10.3846/20294913.2014.949333

[40] Sivilevičius H, Maskeliūnaitè L. The numerical example for evaluating the criteria describing the quality of the trip by international train. E+M Economics and Management $=$ Ekonomie a Management. 2014;17(2): 73-86. Available from: http://dx.doi.org.10.15240/ tul/001/2014-2-006/1648

[41] Zavadskas EK, Podvezko V. Integrated determination of objective criteria weights in MCDM. International Journal of Information Technology \& Decision Making. 2016;15(2): 267-283. Available from: doi: 10.1142/ S0219622016500036

[42] Saaty TL. The Analytic Hierarchy Process. New York: McGraw-Hill; 1980.

[43] Saaty TL. How to make a decision: the analytic hierarchy process. European Journal of Operational Research. 1990;48(1990): 9-26.

[44] Saaty TL, Vargas LG. Models, Methods, Concepts \& Applications of the Analytic Hierarchy Process. Second edition. New York: Springer; 2012.

[45] Kendall ME. Rank Correlation Methods. $4^{\text {th }}$ ed. London: Griffin and Co.; 1970.

[46] Kendall M, Gibbons JD. Rank Correlation Methods. London: Edvard Arnold; 1990.

[47] Podvezko V. Determining the level of agreement of expert estimates. Technological and Economic Development of Economy [Ūkio technologinis ir ekonominis vystymas]. 2005;11(2): 101-107.

[48] Montgomery DC. Statistical Quality Control: A Modern Introduction. $7^{\text {th }}$ ed. Arizona: John Wiley \& Sons, Inc.; 2013.

[49] Saaty TL, Ozdemir MS. Why the magic number seven plus or minus two. Mathematical and Computer Modelling. 2003;38: 233-244. Available from: doi: 10.1016/S0895-7177(03)00216-4

[50] Sivilevičius H. Application of expert evaluation method to determine the importance of operating asphalt mixing plant quality criteria and rank correlation. The Baltic Journal of Road and Bridge Engineering. 2011;6 (1): 48-58. Available from: http://dx.doi.org.10.3846/ bjrbe.2011.07.

[51] Sun C-C. A novel approach for evaluating TFT-LCD manufacturer opreatioal performance. Journal of Testing and Evaluation. 2016;44(3): 1421-1429. Available from: doi:10.1520/JTE20140040.ISSN 0090-3973

[52] [Chen S, Hung H-F. Formative measurement test of supplier evaluation indicators and weight models. Journal of Testing and Evaluation. 2016;44(3): 13501363. Available from: doi:10.1520/JTE20140426. ISSN0090-3913

[53] Saaty TL, Shang JS. An innovative orders of-magnitude approach to AHP-based multi-criteria decision making: Prioritizing divergent intangible humane acts. European Journal of Operational Research. 2011;214: 703715. Available from: doi:10.1016/j.ejor.2011.05.019

[54] Gudienè N, Banaitis A, Podvezko V, Banaitienè N. Identification and evaluation of the critical success factors for construction projects in Lithuania: AHP approach. Journal of Civil Engineering and Management. 2014;20(3): 350-359. Available from: doi:10.3846/1 3923730.2014 .914082 
[55] Chang S-C, Tsai P-H. A hybrid financial performance evaluation model for wealth management banks following the global financial crisis. Technological and Economic Development of Economy. 2016;22(1): 21-46. Available from: doi:10.3846/20294913.2014.986771

[56] Beiler MO, Waksmunski E. Measuring the sustainability of shared-use paths: development of the Green Paths rating system. Journal of Transportation Engineering. 2015;141(11): 04015026-1-10. Available from: doi:10.1061/(ASCE)TE.1943-5436.0000796

[57] Rabbani A, Zamani M, Yardani-Chamzini A, Zavadskas EK. Proposing a new integrated model based on balanced scorecard (SBSC) and MCDM approaches by using linguistic variables for the performance evaluation of oil producing companies. Expert Systems with Applications. 2014;41: 7316-7327. Available from: http:// dx.doi.org/10.1016/j.eswa.2014.05.023 